\title{
Pulse-dose-rate interstitial brachytherapy in anal squamous cell carcinoma: clinical outcomes and patients' health quality perception
}

\author{
Rémi Bourdais, MD', Samir Achkar, MD', Sophie Espenel, MD', Sophie Bockel, MD', Laetitia Chauffert-Yvart, MD², \\ Florence Ravet de Mellis, MD!, Minh-Hanh Ta, MD!, Wassila Boukhelif, MD³, Jérôme Durand-Labrunie, MD', \\ Pascal Burtin, MD!, Christine Haie-Meder, MD!, Eric Deutsch, MD, PhD',4, Cyrus Chargari, MD, PhD!,4.5 \\ 'Brachytherapy Unit, Radiation Oncology Department, Gustave Roussy Cancer Campus, Université Paris-Saclay, Villejuif, France, \\ ${ }^{2}$ Medical Oncology Department, Henri Mondor Hospital, AP-HP, Creteil, France, ${ }^{3}$ Radiation Oncology Department, Centre Hospitalier \\ Intercommunal, Creteil, France, ${ }^{4}$ INSERMIO3O Radiothérapie Moléculaire et Innovations Thérapeutiques, Université Paris-Saclay, Villejuif, France, \\ ${ }^{5}$ French Military Health Academy, Ecole du Val-de-Grâce, Paris, France
}

\begin{abstract}
Purpose: To examine clinical outcomes and quality of life of patients with anal squamous cell carcinoma treated with interstitial pulsed-dose-rate brachytherapy (PDR-BT) with a boost to residual tumor after external radiotherapy.

Material and methods: Medical records of patients receiving a brachytherapy boost after radiotherapy for anal squamous cell carcinoma in our Institute between 2008 and 2019 were retrospectively reviewed. After receiving pelvic irradiation \pm concurrent chemotherapy, patients received PDR-BT boost to residual tumor, in order to deliver a minimal total dose of 60 Gy. Patients' outcomes were analyzed, with primary focus on local control, sphincter preservation, morbidity, and quality of life.

Results: A total of 42 patients were identified, included 24, 13, and 5 patients with I, II, and III tumor stages, respectively. Median brachytherapy (BT) dose was 20 Gy (range, 10-30 Gy). Median dose per pulse was 42 cGy (range, 37.5-50 cGy). With median follow-up of 60.4 months (range, 5.4-127.4 months), estimated local control and colostomy-free survival rates at 5 years were both $88.7 \%$ (95\% CI: 67.4-96.4\%). The largest axis of residual lesion after external beam radiation therapy (EBRT) and poor tumor shrinkage were associated with more frequent relapses $(p=0.02$ and $p=0.007$, respectively). Out of 40 patients with more than 6 months follow-up, only one experienced severe delayed toxicity (fecal incontinence). Health quality perception was very good or good in 20 of 22 (91\%) patients, according to their replies of quality-of-life surveys. A total dose $\geq 63$ Gy was associated with higher number of anorectal grade 1+ toxicities $(n=1.5$ vs. $n=0.61, p=0.02)$.

Conclusions: In this cohort of 42 patients with mainly I and II tumor stages, PDR-BT boost allowed for local control in $88.7 \%$ of patients, with only one grade 3 anorectal toxicity.

Key words: anal squamous cell carcinoma, brachytherapy, pulsed-dose-rate, local control.

\section{Purpose}

Unique dose distribution in brachytherapy (BT) allows for appropriate technique as a part of treatment of anal cancer to focally increase the dose to the tumor while sparing healthy tissues [1]. Analysis of the literature shows that brachytherapy, if used as a boost after radiotherapy or chemoradiotherapy, allows for a high probability of local control with acceptable toxicity [2-6]. Apart from the capability of highly focused dose escalation, another advantage of brachytherapy is its ability to spare the uninvolved part of anal canal in order to minimize the risk of long-term morbidity. The majority of published series refer to low-dose-rate brachytherapy (LDR-BT), which delivers a continuous irradiation, and is optimal in terms of radiobiological aspects. Pulsed-doserate brachytherapy (PDR-BT) aims at reproducing some radiobiological benefits of LDR-BT (from a radiobiological point of view, PDR is not LDR), and provides the capability of optimization of high-dose-rate brachytherapy (HDR-BT) dosimetry. Moreover, PDR-BT is more convenient in terms of radioprotection, as compared to LDR. Few retrospective series on PDR-BT have been published, including a pilot study of our group with a low number

Address for correspondence: Prof. Cyrus Chargari, Brachytherapy Unit, Radiation Oncology Department, Received: 25.12 .2020 Gustave Roussy Cancer Campus, Université Paris-Saclay, 114 rue Edouard Vaillant, 94800 Villejuif, France, Accepted: 07.04.2021 
of patients. Those studies suggested that local control would be as good as in LDR-BT [7-10].

Here, we report our experience of PDR-BT use for boosting residual tumor in anal carcinoma, with a prime focus on patients' outcomes, including functional assessment and health quality perception.

\section{Material and methods}

\section{Patients and tumors}

A retrospective analysis was conducted among consecutive patients with a histological diagnosis of invasive anal squamous cell carcinoma and treated with a PDR-BT boost in our institution (Gustave Roussy Campus, Villejuif, France) from March 2008 to July 2019. Local ethics committees approved the conduct of this study as well as data collection and analysis (reference Gustave Roussy ethics committee 2021-19). Primary staging included a clinical examination, ultrasound endoscopy, abdominal and pelvic computed tomography (CT) scan, pelvic magnetic resonance imaging (MRI), and 18-fluorodeoxyglucose (FDG) positron emission tomography (PET) for T2-T4 or $\mathrm{N}+$ disease. Tumor staging was carried out according to the American Joint Committee on Cancer $8^{\text {th }}$ edition (Table 1).

\section{Brachytherapy implant}

Patients were referred after receiving an external beam radiation therapy (EBRT) irradiating pelvis and inguinal lymph nodes as recommended by the Radiation Therapy Oncology Group, using a 3D conformal EBRT technique, or intensity-modulated radiation therapy with high megavoltage photons [11]. Patients were eligible for PDR-BT if the tumor did not exceed half the circumference of anal canal at diagnosis, and if the thickness of residual tumor did

Table 1. Characteristics of patients and tumors

\begin{tabular}{lc} 
Characteristic & Number (range) \\
\hline Number of patients & 42 \\
\hline Median age & $69(29-85)$ \\
\hline Gender & 35 \\
\hline Female & 7 \\
\hline Male & 25 \\
\hline Stage & 15 \\
\hline T1 & 2 \\
\hline T2 & 37 \\
\hline T3 & 3 \\
\hline N0 & 1 \\
\hline N2 & 1 \\
\hline N3 & $19.5(7-57)$
\end{tabular}

not exceed $5 \mathrm{~mm}$ at the time of brachytherapy, according to the clinical assessment. Female patients with an involvement of anterior anal canal were also eligible for BT boost. The procedure for catheters implantation was described elsewhere [10, 12]. It was performed under general anesthesia. The number of needles was chosen to cover the entire residual gross tumor volume, determined by the clinical examination, with a margin of 5 to $10 \mathrm{~mm}$. In case of a doubt, a specialized gastroenterologist performed a transrectal endoscopic ultrasound to determine clinical target volume (CTV). The implantation followed Paris system rules (in terms of parallelism and equidistance of needles), and needles were inserted and maintained using a ring template with every centimeter perforated (Papillon template). The implant was sutured to the perineum. An anal dilator was inserted and fixed at the end of the implantation and kept in place until completion of the treatment to spare the uninvolved part of anal mucosa from irradiation.

\section{Treatment planning}

Planning was carried out using a computed tomography (CT) scanner with a slice thickness of $1.5 \mathrm{~mm}$. Axial images were imported into Plato brachytherapy planning system (Nucletron ${ }^{\circledR}$, Veenendaal, The Netherlands) or Oncentra brachytherapy planning system $\left(\right.$ Nucletron $\left.^{\circledR}\right)$. Dwell positions of the implant catheters were digitized on each axial computed tomography slice. Activation length was chosen to properly cover the whole anal canal length of the tumor site. Dose was prescribed to the reference isodose, defined as $85 \%$ of the minimal dose-rate isodose between the planes, according to the Paris system. No optimization was performed. Dose distribution is shown in Figure 1.

The prescription dose considered EBRT contribution to deliver a minimum dose of 60 Gy to target volume (tumor residuum $+5-10 \mathrm{~mm}$ margin). PDR-BT was delivered through continuous hourly pulses, with a dose-rate of 0.4 to $0.6 \mathrm{~Gy}$ per hour, 24 hours per day.

\section{Follow-up}

The patients had a proctologic examination at 4-6 weeks after BT, then every 4 months for 2 years, every 6 months for 3 years, and then annually. Transrectal endoscopic ultrasound was performed every 6 months for 5 years. Abdominal and pelvic CT scanner or pelvic MRI was done annually for 5 years. Only radiation-related toxicities, including BT-related toxicities were analyzed. Acute toxicity was defined as a complication occurring within the first three months following BT procedure. Late toxicity was defined as a complication occurring more than three months after BT, according to the common terminology criteria for adverse events (CTCAE), version 5.0. Careful biopsy was only performed in case of progressive lesion in endoscopic ultrasound, after a minimum delay of 6 months after brachytherapy. Abdominal perineal amputation was done as a salvage treatment. Failures were classified according to the site of first relapse: local (anorectal or perineal relapse) or distant relapse (lymph nodes or metastases). Complications were assessed from medical records. In addition, the patients were contacted by telephone by a BT-trained technician for updating 


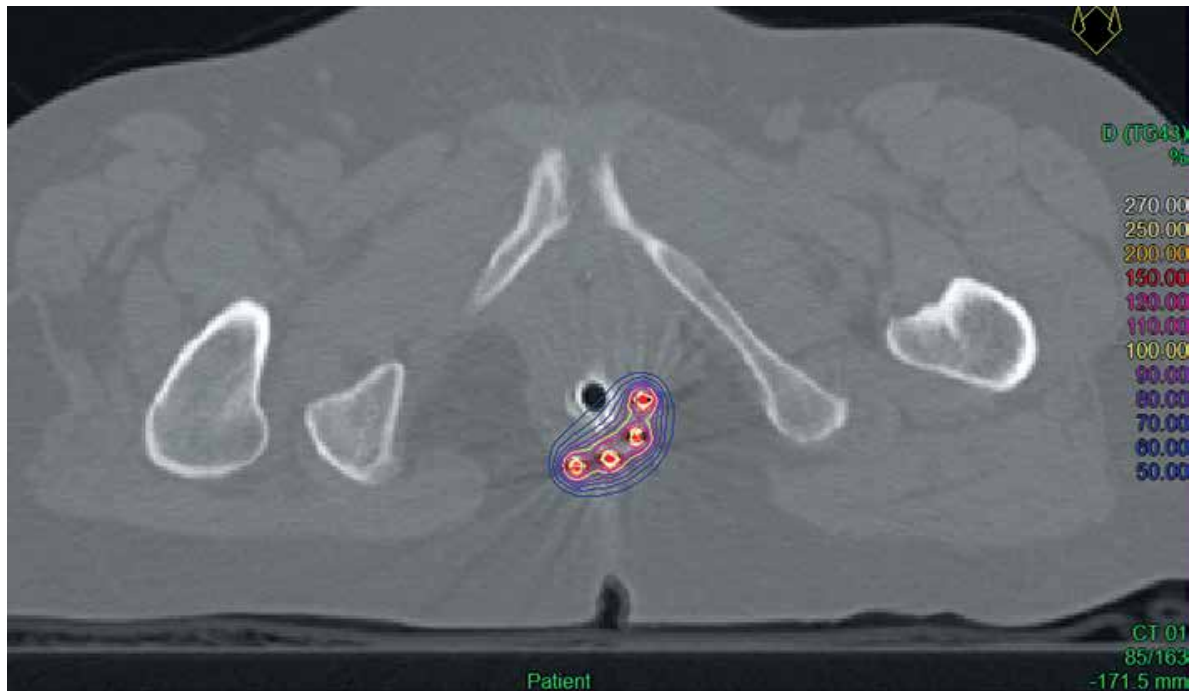

Fig. 1. Example of a brachytherapy boost for posterolateral residual lesion in a T1 squamous cell carcinoma of the anal canal (axial view). $100 \%$ isodose (20 Gy) is shown in yellow. $50 \%$ isodose (10 Gy) is shown in blue. Contralateral uninvolved anal canal and vagina are almost totally spared from irradiation

medical records in terms of toxicities. In addition to this update, a telephone interview was carried out to assess patient health quality perception, with items derived from the EORTC quality of life questionnaire (Appendix).

\section{Statistical analysis}

Overall survival (OS), progression-free survival (PFS), local relapse (LR), and distant relapse (DR) rates were estimated using Kaplan-Meier method. Follow-up was calculated from the time between the date of BT to the last follow-up or to the first event. Late digestive, urinary, and gynecological (in females) effects were examined. The total number of late effects were compared with Mann-Whitney test for categorical variables. Categorical variable association analyses were performed with Fisher's exact test. Median relative tumor shrinkage was estimated with the following formula:

\section{largest axis at diagnosis - largest axis at BT}

largest axis at diagnosis

Largest axis at BT time was measured by clinical examination performed under general anesthesia. Anorectal complications were more specifically examined, included rectal bleeding, anal pain, and sphincter dysfunction symptoms. Analyses of the association between the risk of relapse or toxicity and a continuous variable were performed using a logistic regression. All reported $p$-values were two-sided, and $p$-values less than 0.05 were considered significant. All analyses were performed using Prism software, version 5.0.

\section{Results}

\section{Patients, tumors, and treatments prior to brachytherapy}

A total of 42 patients were identified, including 24, 13 , and 5 patients with I, II, and III tumor stages, respec- tively. The median age of patients at the time of BT was 69 years (range, 29 to 85 years). The gender ratio was 0.2 (7 males and 35 females). All patients had received EBRT prior to BT boost. A 3D conformal EBRT technique was used in 23 patients, and an intensity-modulated method was applied in 19 patients. The median EBRT dose to the tumor and the elective nodal volume were $44 \mathrm{~Gy}$ (range, 30-54 Gy) and 44 Gy (range, 30.6-54 Gy), respectively. A dose to nodal boost in case of node-positive disease ranged from 50 to $60 \mathrm{~Gy}$. Doses were delivered in fractions of 1.8 to $2 \mathrm{~Gy}$, five fractions per week, except for one patient who received bi-fractionated radiation therapy at a dose of $30 \mathrm{~Gy}$ with two daily fractions of $1.5 \mathrm{~Gy}$ because of a previous history of post-operative brachytherapy for cervical cancer (60 Gy LDR-BT). The median total duration of external radiotherapy was 32 days (range, 20-77 days). Concomitant chemotherapy was delivered in $16 \mathrm{pa}-$ tients $(38 \%)$, with II or III tumor stages. Chemotherapy regimens consisted of mitomycin C plus 5-fluorouracil were applied in 10 patients and cisplatin plus 5-fluorouracil in six patients.

For the 5-FU mitomycin $\mathrm{C}$ regimen, mitomycin $\mathrm{C}$ was administered at a dose of $10 \mathrm{mg} / \mathrm{m}^{2}$ at D1 and D29. 5 -FU was administered at a dose of $1000 \mathrm{mg} / \mathrm{m}^{2} / \mathrm{d}$ over 5 days, on D1 and D29. For the 5-FU cisplatin regimen, cisplatin was administered at a dose of $100 \mathrm{mg} / \mathrm{m}^{2}$ on D1. 5 -FU was administered at a dose of $800 \mathrm{mg} / \mathrm{m}^{2} / \mathrm{d}$ over 5 days, on D1 and D29. For both chemotherapy regimens, chemotherapy was not repeated during brachytherapy.

\section{Brachytherapy characteristics}

Brachytherapy was performed within a median time interval of 3.3 weeks (interquartile range, 1.8-4.6 weeks), following EBRT completion. The median overall treatment time calculated from the first EBRT fraction to brachytherapy completion was 55 days (interquartile range, 44-67 days). Fifteen patients had a complete response after EBRT. Among patients with residual disease, 
the largest median axis diameter of the residual tumor at the time of BT was $15 \mathrm{~mm}$ (range, 3-30 $\mathrm{mm}$ ), and the mean and median residual tumor thickness were $4 \mathrm{~mm}$ and

Table 2. Characteristics of treatment

\begin{tabular}{|c|c|}
\hline EBRT parameters & $n$ (range) \\
\hline Mean/median dose to tumor (Gy) & $42.18 / 44(30-54)$ \\
\hline $\begin{array}{l}\text { Mean/median dose to elective nodal } \\
\text { volumes (Gy) }\end{array}$ & $42.0 / 44(30.6-54)$ \\
\hline Median number of fractions & $22(18-27)$ \\
\hline Median total duration (days) & $32(20-77)$ \\
\hline Concomitant chemotherapy (\%) & $16(38)$ \\
\hline CDDP-5FU (\%) & $6(14)$ \\
\hline MMC-5FU (\%) & $10(24)$ \\
\hline Brachytherapy parameters & $n$ (range) \\
\hline Mean/median dose (Gy) & $19.73 / 20(10-30)$ \\
\hline Mean/median total dose & $61.94 / 60(57.8-69.8)$ \\
\hline Median time interval from EBRT (days) & $23.5(2-99)$ \\
\hline Median number of needles & $3(2-4)$ \\
\hline Median pulse number & $48(20-80)$ \\
\hline Median dose per pulse (cGy) & $42(37.50-50)$ \\
\hline Distance between dwell positions ( $\mathrm{mm}$ ) & 5 \\
\hline Median time per pulse (s) & $198(99-436)$ \\
\hline Median treated length (mm) & $45(25-60)$ \\
\hline Median treated volume $\left(\mathrm{cm}^{3}\right)$ & 9.7 \\
\hline Median over dosage volume $\left(\mathrm{cm}^{3}\right)$ & 1.7 \\
\hline
\end{tabular}

$5 \mathrm{~mm}$ (range, 1-10 $\mathrm{mm}$ ), respectively. The implantation of the needles was performed in one plan for all the patients. In two patients, a second brachytherapy procedure was performed to improve needles positioning. The median number of needles was 3 (range, 2-4). Themedian activation length per needle was $45 \mathrm{~mm}$ (range, $25-60 \mathrm{~mm}$ ). The median number of pulses was 48 (range, $20-80$ pulses). The median dose per pulse was 42 cGy (range, 37.50-50 cGy). The median pulse time was $198 \mathrm{~s}$ (range, 99-436 s).

The mean and median physical doses delivered through BT were 19.73 Gy and $20 \mathrm{~Gy}$, respectively (range, 10-30 Gy). The mean and median total physical doses delivered (EBRT + BT boost) were 61.94 Gy and 60 Gy (range, 57.84-69.80 Gy). Applying the linear-quadratic model (using an $\alpha / \beta$ ratio of $10 \mathrm{~Gy}$ for tumor target and half-time of 1.5 hours for normal tissues damages repair), the median radiobiologically weighted dose equivalent of $2 \mathrm{~Gy} /$ fraction was $19.7 \mathrm{~Gy} \mathrm{EQD}_{2}$ for BT boost and $59.7 \mathrm{~Gy} \mathrm{EQD} \mathrm{E}_{2}$ for total dose, including EBRT contribution. The median treated volume $\left(\mathrm{V}_{100 \%}=\right.$ volume encompassed by the reference isodose) was $9.7 \mathrm{~cm}^{3}$ (range, 4.5-34.28 $\mathrm{cm}^{3}$ ). The median overdose volume $\left(\mathrm{V}_{200 \%}=\right.$ volume encompassed by the $200 \%$ isodose) was $1.7 \mathrm{~cm}^{3}$ (range, $0.4-7.3 \mathrm{~cm}^{3}$ ) (Table 2).

\section{Disease control}

With a median follow-up of 60.4 months (range, 9.3-127.4 months), a total of five patients (12\%) experienced tumor relapse, including three patients $(7.1 \%)$ with local relapse as the first event and two patients with metastatic failure only (Table 3). In these patients, time intervals from BT to local relapse were 8,17 , and 59 months. Two of these patients had stage II tumor at diagnosis and one had stage III. At BT time, tumor axes were 15-, 15-, and 20-mm. BT doses were $15 \mathrm{~Gy}, 30 \mathrm{~Gy}$, and 15.2 Gy for a total dose to the tumor of $60 \mathrm{~Gy}$. Time intervals from EBRT to BT were 10, 31, and 41 days. Local relapses were treated with abdominal perineal resection. All the three

Table 3. Patterns of recurrences

\begin{tabular}{|c|c|c|c|c|c|c|c|c|c|}
\hline Patient & Stage & $\begin{array}{l}\text { EBRT dose to } \\
\text { tumor }\end{array}$ & $\begin{array}{l}\text { Time inter- } \\
\text { val from } \\
\text { EBRT to BT } \\
\text { (days) }\end{array}$ & $\begin{array}{l}\text { Tumor } \\
\text { largest axis } \\
\text { at BT }\end{array}$ & BT dose & Relapse & $\begin{array}{l}\text { Time to } \\
\text { relapse }\end{array}$ & $\begin{array}{l}\text { Patterns of } \\
\text { recurrence }\end{array}$ & $\begin{array}{l}\text { Salvage } \\
\text { treatment }\end{array}$ \\
\hline 1 & T2N3 & 44 Gy/22 fx & 10 & $15 \mathrm{~mm}$ & 15 Gy & Local & 8 months & $\begin{array}{l}\text { Transrectal } \\
\text { endoscopic } \\
\text { ultrasound }\end{array}$ & $\begin{array}{c}\text { Abdominal } \\
\text { perineal } \\
\text { resection }\end{array}$ \\
\hline 2 & $\mathrm{~T} 2 \mathrm{NO}$ & $\begin{array}{c}30 \text { Gy (2 daily fx } \\
\text { of } 1.5 \text { Gy) }\end{array}$ & 31 & $15 \mathrm{~mm}$ & 30 Gy & Local & 59 months & $\begin{array}{l}\text { Transrectal } \\
\text { endoscopic } \\
\text { ultrasound }\end{array}$ & $\begin{array}{c}\text { Abdominal } \\
\text { perineal } \\
\text { resection }\end{array}$ \\
\hline 3 & $\mathrm{~T} 2 \mathrm{NO}$ & 45 Gy/25 fx & 41 & $20 \mathrm{~mm}$ & 15 Gy & Local & 17 months & $\begin{array}{l}\text { Clinical ex- } \\
\text { amination }\end{array}$ & $\begin{array}{c}\text { Abdominal } \\
\text { perineal } \\
\text { resection }\end{array}$ \\
\hline 4 & T3NO & 36 Gy/20 fx & $\begin{array}{l}2 \text { days after } \\
\text { end of pelvic } \\
\text { EBRT ( } 45 \\
\text { Gy/25 fx) }\end{array}$ & $15 \mathrm{~mm}$ & 24 Gy & $\begin{array}{c}\text { Hepat- } \\
\text { ic and } \\
\text { peritoneal } \\
\text { metastases }\end{array}$ & 47 months & Hepatalgia & $\begin{array}{l}\text { Chemo- } \\
\text { therapy }\end{array}$ \\
\hline 5 & T1NO & 50 Gy/25 fx & 23 & $18 \mathrm{~mm}$ & 10 Gy & $\begin{array}{l}\text { Lung me- } \\
\text { tastases }\end{array}$ & 34 months & CT scanner & $\begin{array}{l}\text { Cryother- } \\
\text { apy }\end{array}$ \\
\hline
\end{tabular}

EBRT - external beam radiotherapy, BT - brachytherapy, fx-fractions, CT - computed tomography 


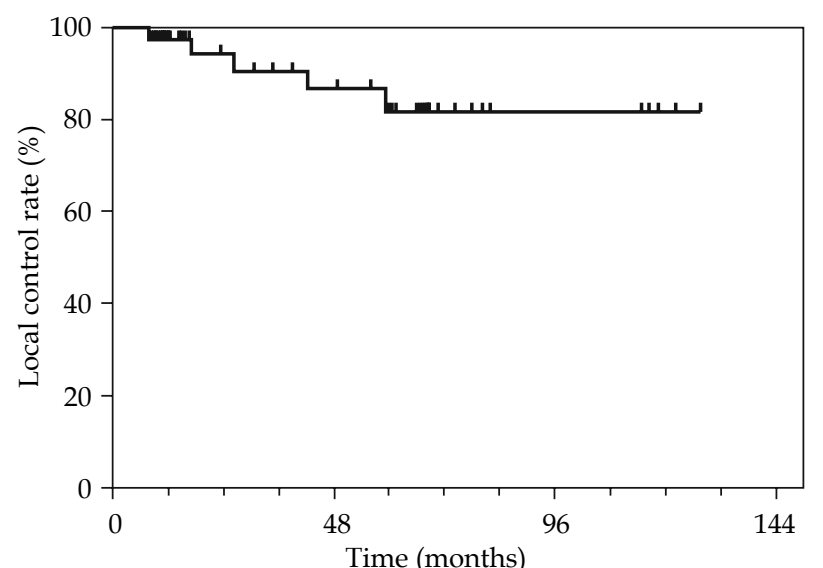

$\begin{array}{llllll}\text { At risk } 42 & 27 & 21 & 10 & 6 & 3\end{array}$

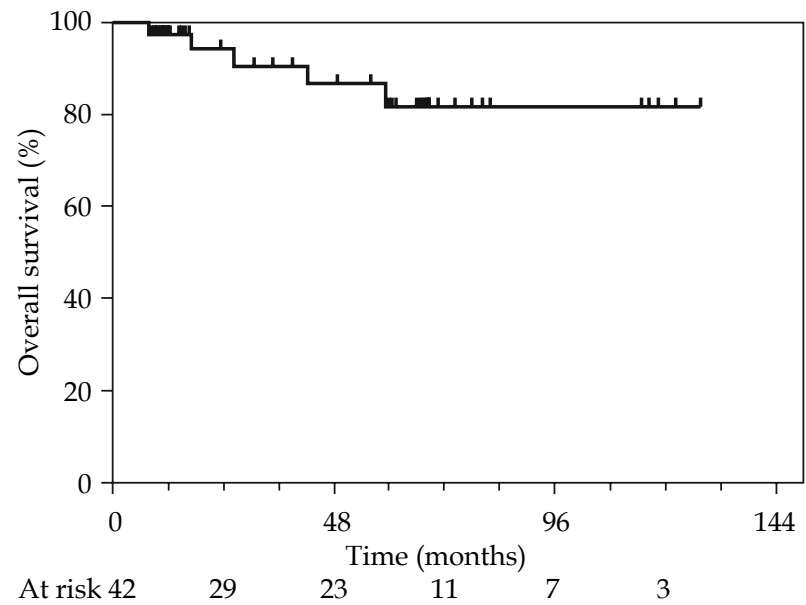

patients who had a local relapse, subsequently developed metastases. Two of them died of cancer. No patient with stage I disease experienced local relapse.

Thirty-eight patients $(90 \%)$ were alive at last follow-up. Overall local control (LC) rates at 2 and 5 years were $93.9 \%$ (95\% CI: $77.4-98.5 \%$ ) and $88.7 \%$ (95\% CI: 67.4-96.4\%), respectively. Estimated disease-free survival probabilities at 2- and 5-year were 93.9\% (95\% CI: 77.4$98.5 \%$ ) and $81.2 \%$ (95\% CI: 59.8-91.9\%), respectively. Colostomy-free survival (CFS) rates at 2 and 5 years were 94\% (95\% CI: 77.5-98.5\%) and 88.7\% (95\% CI: 67.4-96.4\%), respectively. Overall survival rates at 2 and 5 years were $100 \%$ and $92.1 \%$ (95\% CI: 71.9-98.0\%), respectively. Survival curves are presented in Figure 2.

In univariate analysis, the largest axis of the residual lesion after EBRT was predictive for the overall risk of relapse $(p=0.02)$. The total tumor dose, initial tumor stage, and time interval between EBRT and brachytherapy were not associated with the risk of relapse $(p=0.7$, $p=0.14$, and $p=0.43$, respectively). The median tumor relative shrinkage was $69 \%$ in the whole cohort; $85 \%$ among the 39 patients without local relapse and $54 \%$ among the three patients who experienced local failure. All relapses, including tumor shrinkage was $85 \%$ among patients without relapse vs. $34 \%$ among patients with tumor relapse $(p=0.007)$. Pre-treatment leukocyte count was

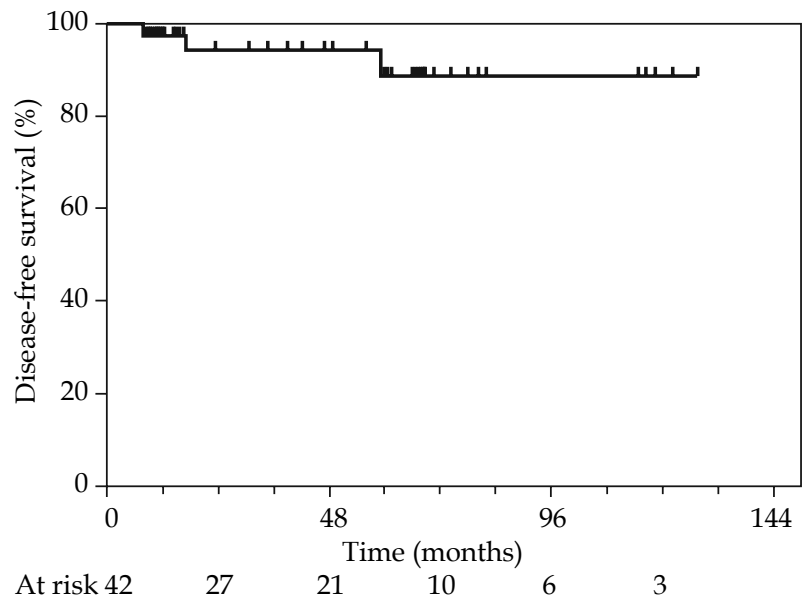

Fig. 2. Kaplan-Meier estimated local control and survival curves

$4.8 \mathrm{~g} / \mathrm{l}$ among patients without relapse, vs. $8.9 \mathrm{~g} / \mathrm{l}$ among patients with a relapse (not significant). No multivariate analysis was performed due to low number of events.

\section{Toxicity}

All included patients were analyzed for acute toxicities, which ranged from mild to moderate. One patient experienced a grade 2 anal abscess that required antibiotics and local antiseptic care. Eleven patients (26\%) experienced grade 1-2 diarrhea, four patients had a transient and spontaneously resolving acute anal incontinence. No grade 3 or more acute toxicity was reported.

Long-term toxicities assessed among patients free from local relapse $(n=39)$ are presented in Table 4 . No patient required surgery for toxicity. No biopsy-induced ulceration or necrosis was observed in the absence of local recurrence. Grade 1-2 toxicities were as follows: 14 patients $(36 \%)$ experienced grade 1 perineal telangiectasia, six $(15 \%)$ and three $(8 \%)$ patients $(21 \%)$ had grade 1 and grade 2 diarrhea, respectively. Nine patients had intermittent grade 1 rectal bleeding, and six patients had episodic grade 1 anal pain. A total of six patients had anal sphincter dysfunction symptoms: four had grade 1 fecal incontinence, one had grade 2 symptoms, and one patient had a grade 3 fecal incontinence. Regarding urinary dis- 
Table 4. Long-term toxicity according to CTCAE v.5

\begin{tabular}{lcccc}
$\begin{array}{l}\text { Long-term toxicity } \\
(n=39)\end{array}$ & Grade 1 (\%) & Grade 2 (\%) & Grade 3 (\%) & Grade 4 (\%) \\
\hline Telangiectasia & $14(36)$ & 0 & - & - \\
\hline Diarrhea & $6(15)$ & $3(8)$ & 0 & 0 \\
\hline Rectal bleeding & $9(23)$ & 0 & 0 & - \\
\hline Anal pain & $6(15)$ & 0 & $1(3)$ & - \\
\hline Fecal incontinence & $4(10)$ & $1(3)$ & 0 & -
\end{tabular}

orders, one patient had intermittent low-level dysuria. Six patients had urinary leakage occurring at most once a week, caused by coughing or effort. Four of these patients reported wearing daily protection. Fourteen patients reported getting up at night to urinate: once $(n=6)$, twice or three times $(n=7)$, four or five times $(n=1)$ per night. Regarding gynecological disorders, 3 of 19 female patients experienced vaginal dryness, and two used lubricants during sexual intercourse. None of the patients complained of vaginal shortening. None of the patients used a vaginal dilator., and no patient had vaginal bleeding.

In details, the only patient with grade 3 incontinence was the one who had an acute anal abscess treated by antibiotics. He was treated for a T1N0 tumor and received 44 Gy EBRT, with three needles implanted. Dose delivered with BT was $20 \mathrm{~Gy}$, for a total dose to the tumor of $64 \mathrm{~Gy}$. Dose per pulse was $50 \mathrm{cGy}$, which was the highest dose-rate reported in this series. Treated volume was $7.13 \mathrm{~cm}^{3}$. Active length per needle was $45 \mathrm{~mm}$.

\section{Self-rated health perception}

A total of 22 patients completed the telephone interview to assess self-rated health perception. For them, the median follow-up from BT completion was 42.2 months (range, 9.3-127.4 months). The median age was 71 years (range, 58-95 years), and included 19 women and 3 men. None of them experienced local or metastatic tumor relapse. Results for self-rated health perception were as follows: very good, good, and poor in $23 \%(n=5), 68 \%$ $(n=15)$, and $9 \%(n=2)$, respectively. No correlation was found between good quality of life and occurrence of grade $1+$ toxicities $(p=0.1)$. Twelve patients reported a restriction in daily activities, at high intensity efforts $(n=11)$ or low intensity effort $(n=1)$. Both grade 1 and 2 asthenia were reported in seven patients. Four patients had intermittent grade 1 pelvic pain. Nine patients reported psychological effects with intermittent $(n=7)$ or frequent $(n=2)$ feeling of sadness.

\section{Factors of toxicity}

A total prescription dose $\geq 63$ Gy was associated with a higher number of anorectal (including rectal bleeding, anal pain, and sphincter dysfunction symptoms) grade $1+$ toxicities ( $n=1.5$ vs. $0.61, p=0.02)$. A BT dose $\geq 20$ Gy was associated with a higher incidence of grade 1+ diarrhea $(p=0.02)$. No correlation was found between the treated volume $\left(\mathrm{V}_{100 \%}\right)$ and the risk of any grade $1+$ toxicity $(p=0.6)$, or any specific grade $1+$ toxicity (not significant for telangiectasia, fecal urgency, anal pain, diarrhea, fecal incontinence, or rectal bleeding). The hyperdose sleeves volume (volume receiving at least $200 \%$ of the reference isodose) was also not a prognostic factor of the risk of complication $(p=0.89)$.

\section{Discussion}

External beam radiation therapy $( \pm$ concurrent chemotherapy) is the standard treatment for anal canal cancers, allowing a local control of $68 \%$ to $87 \%$ at 5 years, depending on the stage of tumor [13-15]. The use of BT is an option as a boost modality after EBRT, yielding high local control probability for acceptable toxicity rates. Historically, boosting the anal primary cancer through brachytherapy implied using LDR sources. Papillon et al. [3] reported on a series of 221 patients suitable for sphincter conservation and treated with a splitcourse regimen, combining external beam radiotherapy at $35 \mathrm{~Gy}$ in 15 fractions and interstitial LDR-BT boost to a dose of 15-20 Gy to the initially involved volume, with a short course of 5-fluorouracil and mitomycin $\mathrm{C}$. Tumor control without colostomy was obtained in $80.5 \%$ of patients, and $77 \%$ of local recurrences occurred in T3-T4 patients. Peiffert et al. [5] conservatively treated 101 patients with a split-course of EBRT with concurrent chemotherapy, followed by LDR-BT after a 2-monthsfree interval. At 5 years, local control was obtained in $80 \%$ of patients and overall survival was $60 \%$. In our series, overall local control rate at 5 years was comparable to data previously published on LDR-BT, confirming the effectiveness of PDR-BT in selected patients, with mainly I-II tumor stages and those who responded well to EBRT.

Pulsed-dose-rate brachytherapy was developed to replace iridium-192 wires. A recent systematic literature review analyzed the results of 10 retrospective studies reporting on BT boost, including three studies using PDR technology [16]. Median 5-year estimated LC, CFS, DFS, and OS rates were $78.6 \%, 76.1 \%, 75.8 \%$, and $69.4 \%$, respectively. PDR-BT data were less available due to more recent use (Table 5). Only one of three series using PDRBT (47 patients with predominantly advanced tumors, 
as only $44.7 \%$ were stage $\mathrm{T} 1-\mathrm{T} 2)$, reported outcomes at 5 years $(\mathrm{LC}=75.0 \%, \mathrm{CFS}=76.1 \%$, DFS $=75.0 \%$, OS $=$ $65.0 \%$ ) [17]. The second study involving 71 patients, reported a 2-year CSF of $89 \%$ [7], whereas in the third one, 5 -year LC rate was $78.6 \%$ for 209 patients treated with BT boost, and included 58 patients receiving PDR-BT. This series did not differentiate outcomes between PDR-BT and LDR-BT [18]. Recently, a large retrospective study on PDR-BT boost after EBRT in more than 120 patients was published. With a median follow-up of 71 months and with $51.2 \%$ stages T1-T2 tumors, local control rate at 5 years was $81.7 \%$ [9]. In our retrospective analysis on 42 patients with T1-T2 tumors treated with EBRT followed by PDR-BT boost, local control was almost $94 \%$ at 2 years and $89 \%$ at 5 years. These results compare rather favorably with those from the literature in terms of local control after PDR-BT. This is probably a consequence of patients' selection, as we mainly included patients at an early stage of the disease. However, our results also com- pare favorably with published data that used EBRT boost plus concomitant chemotherapy for low-stage tumors. In the Trans-Tasman Radiation Oncology Group (TROG)9902 trial, local control rate and colostomy-free survival probability at 4 years for patients with T1-T2 tumors treated with EBRT (50.4 Gy to the anal canal and $36 \mathrm{~Gy}$ to the pelvis) and with 5FU-mitomycin C, were $82 \%$ and $85 \%$, respectively [19]. While two thirds of our patients did not receive concomitant chemotherapy, we may hypothesize that dose escalation afforded by brachytherapy may yield similar local control probability as a strategy based on chemoradiation with lower EBRT doses. Retrospective data evaluating boost modality suggested that BT was superior to EBRT boost when overall treatment time was $<80$ days [20]. In our series, the median interval time between EBRT and BT boost was approximately 3 weeks, which was quite a long time in relation with the fact that various patients were referred for BT boost after receiving EBRT in another center.

Table 5. Retrospective series on pulsed-dose-rate brachytherapy

\begin{tabular}{|c|c|c|c|c|c|c|c|}
\hline $\begin{array}{l}\text { Authors } \\
\text { (reference) }\end{array}$ & $\begin{array}{l}\text { Number } \\
\text { of pa- } \\
\text { tients }\end{array}$ & Stage (\%) & $\begin{array}{l}\text { EBRT dose (Gy)/number } \\
\text { of fractions, volumes }\end{array}$ & Chemotherapy & $\begin{array}{l}\text { BT boost me- } \\
\text { dian total dose } \\
\text { (range), } \\
\text { technique }\end{array}$ & Outcomes & $\begin{array}{l}\text { Late toxicity } \\
\text { (\%) }\end{array}$ \\
\hline $\begin{array}{l}\text { Gryc et al. } \\
\text { [17] }\end{array}$ & 47 & $\begin{array}{c}\text { T1: } 8.0 \\
\text { T2: } 36.2 \\
\text { T3: } 38.3 \\
\text { T4: } 14.9 \\
\text { N0: } 68.9 \\
\text { N1: } 11.1 \\
\text { N2: } 10.0 \\
\text { N3: } 6.8\end{array}$ & $\begin{array}{c}50.4 \text { Gy/28 boost (T1): } \\
5.4 \text { Gy; } \\
\text { boost }(\geq T 2): 9 \text { Gy, } \\
A R+P N+I N\end{array}$ & $\begin{array}{c}5-F U+M M C: 93 \% \\
5-F U+C D D P: 2.3 \% \\
5-F U: 2.3 \%\end{array}$ & $\begin{array}{c}15.5 \mathrm{~Gy} \\
(8-35.8) \\
\text { PDR }\end{array}$ & $\begin{array}{l}5 \text { years: } \\
\text { LC: } 75 \% \\
\text { CSF: } 66.1 \% \\
\text { DFS: } 75 \% \\
\text { OS: } 65 \%\end{array}$ & $\begin{array}{c}\text { G3-4: } \\
\text { proctitis: } 16.0 ; \\
\text { diarrhea: } 3.0\end{array}$ \\
\hline $\begin{array}{l}\text { Bruna et al. } \\
\text { [7] }\end{array}$ & 71 & $\begin{array}{c}\text { T1: } 19.7 \\
\text { T2: } 57.7 \\
\text { T3: } 21.1 \\
\text { T4: } 1.4 \\
\text { N0: } 73.2 \\
\text { N1: } 18.3 \\
\text { N2: } 4.2 \\
\text { N3: } 4.2\end{array}$ & $\begin{array}{c}\text { Mean dose: } 45.5 \text { Gy/25; } \\
\text { AR + PN + IN (24\%) }\end{array}$ & $5-F U$ + CDDP: $66.1 \%$ & $\begin{array}{l}17.8 \text { Gy } \\
(10-25), \\
\text { PDR }\end{array}$ & $\begin{array}{l}2 \text { years: } \\
\text { LC: } 91 \% \\
\text { CSF: } 89 \% \\
\text { DFS: } 91 \% \\
\text { OS: } 90 \%\end{array}$ & $\begin{array}{l}\text { G3 toxicity } \\
\text { (pain, bleeding, } \\
\text { fecal incon- } \\
\text { tinence, or } \\
\text { necrosis): } 14.0 \text {, } \\
\text { G4 radionecro- } \\
\text { sis: } 2.8\end{array}$ \\
\hline $\begin{array}{l}\text { Lestrade } \\
\text { et al. [18] }\end{array}$ & 219 & $\begin{array}{c}\text { T1: } 12.4 \\
\text { T2: } 46.9 \\
\text { T3: } 38.8 \\
\text { T4: } 2.4 \\
\text { N0: } 72.3 \\
\text { N1: } 17.2 \\
\text { N2: } 7.2 \\
\text { N3: } 3.3\end{array}$ & $\begin{array}{c}45 \mathrm{~Gy} / 25, \mathrm{AR}+\mathrm{PN}+\mathrm{IN} \\
(19.0 \%)\end{array}$ & $\begin{array}{l}5-F U+C D D P: 49.7 \% \\
5-F U+M M C: 14.8 \%\end{array}$ & $\begin{array}{l}18 \text { Gy }(10-31.7) \\
\operatorname{LDR}(72.2 \%) / \\
\operatorname{PDR}(27.8 \%)\end{array}$ & $\begin{array}{c}5 \text { years: } \\
\text { LC: } 78.6 \% \\
\text { CSF: } 79.4 \% \\
\text { DFS: } 80.9 \% \\
\text { OS: } 69.4 \%\end{array}$ & $\begin{array}{l}\text { G3-4 anorectal } \\
\text { toxicity: } 6.3\end{array}$ \\
\hline $\begin{array}{l}\text { Arcelli et al. } \\
\text { [9] }\end{array}$ & 123 & $\begin{array}{c}\text { T1: } 14.6 \\
\text { T2: } 36.6 \\
\text { T3: } 33.3 \\
\text { T4: } 15.4 \\
\text { N0: } 56.9 \\
\text { N1: } 22.8 \\
\text { N2: } 10.5 \\
\text { N3: } 9.8\end{array}$ & 45 Gy/25 & 5-FU + MMC: $94 \%$ & 20 Gy (13-25) & $\begin{array}{c}5 \text { years: } \\
\text { LC: } 81.7 \% \\
\text { CSF: } 62.3 \% \\
\text { DFS: } 92.3 \% \\
\text { OS: } 74.0 \%\end{array}$ & $\begin{array}{l}\text { G4 anorectal } \\
\text { toxicity: } 4.9\end{array}$ \\
\hline
\end{tabular}

$A R$ - anal region, $P N$ - pelvic lymph nodes, IN - inguinal lymph nodes, 5-FU - 5-fluorouracil, MMC-mitomycin C, CDDP - cisplatin, LC - local control, CSF-colostomy-free survival, DFS - disease-free survival, OS - overall survival 
In addition to the possibility to apply focal dose escalation, one advantage of brachytherapy is to spare the non-involved part of the anal canal. In our series, low levels of acute and chronic toxicity were observed. No acute grade $3+$ toxicity was noted, and only one severe late morbidity occurred (fecal incontinence). No surgery or colostomy was indicated due to toxicity. Other authors reported $14 \%$ of grade $3+$ chronic anal toxicities and $2.8 \%$ of grade 4 radionecrosis after PDR-BT boost [7]. With 5-year median follow-up, we observed much less chronic toxicities. This may be explained by a smaller volume of treatment, limited to the residual tumor as well as proper patients' selection. Furthermore, only patients with good response were included, and only one brachytherapy plane (which is enough to treat tumors less than $5 \mathrm{~mm}$ thick) was used. Another explanation could be that our median dose-rate did not exceed 0.5 Gy per hour, though such correlation between dose-rate and chronic toxicity was not demonstrated in anal canal cancer. We observed an association between total dose to the tumor and late toxicities, in line with previous data from Peiffert et al. [5], who reported that a brachytherapy dose > 20 Gy was associated with increased late severe complications [5].

A limitation of this study is the heterogeneity of external radiotherapy and chemotherapy protocols due to the fact that patients were referred only for brachytherapy boost, after receiving radiotherapy in various centers. A strength and originality of this study is the evaluation of patients' health quality perception. More than half of the patients responded to the survey allowing a detailed analysis of delayed toxicity, including gynecological morbidity. Systematic collection of toxicities by questionnaire should therefore be encouraged in daily clinical activities. More than $90 \%$ of the patients reported good or very good quality of life, suggesting excellent functional results of this technique. Furthermore, we observed that tumor shrinkage at the time of BT was correlated with probability of a relapse. Such data had been shown in larger cohorts with locally advanced cervical cancer patients who shared some histopathological similarities with anal cancer [21]. This suggests that tumor response on EBRT could be an indicator for a treatment intensification through systemic approaches or dose escalation strategies, which still need to be examined. In the same way, pre-treatment leukocytosis could be relevant for identifying patients at a high-risk of relapse. In our series, the pre-treatment leukocyte count was $4.8 \mathrm{~g} / 1$ among patients without relapse versus $8.9 \mathrm{~g} / 1$ in patients with a relapse. The difference was not significant, possibly due to insufficient statistical power (10 patients receiving EBRT in another center without pre-treatment leucocyte count). However, a larger study suggested an effect in various squamous cell carcinoma types, including anal cancer [22-24].

\section{Conclusions}

With almost 5 years median follow-up, this study confirms that an approach based on PDR-BT to boost the tumor bed is effective and safe in this indication for selected patients with mainly stage I tumors. Local con- trol rate was comparable with historical data on LDR-BT. Morbidity profile was favorable, possibly as a consequence of accurate patients' selection and technique used (one implant plane and small treated volumes). Most patients reported good or very good quality of life. Tumor shrinkage was associated with more favorable outcome, suggesting the need for further systemic intensification or dose escalation in patients with poor tumor response. In this context, BT is a good technique to focally increase the dose, provided that patients' selection criteria and implant rules are carefully followed.

\section{Disclosure}

Cyrus Chargari reports personal fees and non-financial support from Takeda, MSD, GSK, and Elekta outside the submitted work as well as support for clinical research from TherAgulX and Roche.

Eric Deutsch reports grants and personal fees from Roche, AstraZeneca, Merck Serono, and Boehringer; grants from Servier, Bristol-Myers-Squibb, and MSD as well as and personal fees from Amgen and Accuray outside the submitted work.

Other authors report no conflict of interest.

The authors report no proprietary or commercial interest in any product mentioned or concept discussed in this article.

\section{References}

1. Chargari C, Deutsch E, Blanchard P et al. Brachytherapy: an overview for clinicians. CA Cancer J Clin 2019; 69: 386-401.

2. Glynne-Jones R, Nilsson PJ, Aschele $C$ et al. Anal cancer: ESMO-ESSO-ESTRO clinical practice guidelines for diagnosis, treatment and follow-up. Radiother Oncol 2014; 111: 330339.

3. Papillon J, Montbarbon JF. Epidermoid carcinoma of the anal canal. A series of 276 cases. Dis Colon Rectum 1987; 30: 324-333.

4. Chapet O, Gerard JP, Riche B et al. Prognostic value of tumor regression evaluated after first course of radiotherapy for anal canal cancer. Int J Radiat Oncol Biol Phys 2005; 63: 1316-1324.

5. Peiffert D, Bey P, Pernot M et al. Conservative treatment by irradiation of epidermoid carcinomas of the anal margin. Int J Radiat Oncol Biol Phys 1997; 39: 57-66.

6. Hwang JM, Rao AR, Cosmatos HA et al. Treatment of T3 and $\mathrm{T} 4$ anal carcinoma with combined chemoradiation and interstitial 192Ir implantation: a 10-year experience. Brachytherapy 2004; 3: 95-100.

7. Bruna A, Gastelblum P, Thomas L et al. Treatment of squamous cell anal canal carcinoma (SCACC) with pulsed dose rate brachytherapy: a retrospective study. Radiother Oncol 2006; 79: 75-79.

8. Roed H, Engelholm SA, Svendsen LB et al. Pulsed dose rate (PDR) brachytherapy of anal carcinoma. Radiother Oncol 1996; 41: 131-134.

9. Arcelli A, Buwenge M, Macchia G et al. Long-term results of chemoradiation plus pulsed-dose-rate brachytherapy boost in anal canal carcinoma: A mono-institutional retrospective analysis. J Contemp Brachytherapy 2019; 11: 21-27.

10. Boukhelif W, Ferri-Molina M, Mazeron R et al. Interstitial pulsed-dose-rate brachytherapy for the treatment of squamous cell anal carcinoma: a retrospective single institution analysis. Brachytherapy 2015; 14: 549-553.

11. Myerson RJ, Garofalo MC, El Naqa I et al. Elective clinical target volumes for conformal therapy in anorectal cancer: 
a Radiation Therapy Oncology Group consensus panel contouring atlas. Int J Radiat Oncol 2009; 74: 824-830.

12. Gerbaulet A, Pötter R, Mazeron JJ et al. The GEC ESTRO Handbook of Brachytherapy 2002.

13. Epidermoid anal cancer: results from the UKCCCR randomised trial of radiotherapy alone versus radiotherapy, 5-fluorouracil, and mitomycin. Lancet 1996; 348: 1049-1054.

14. Bartelink H, Roelofsen F, Eschwege F et al. Concomitant radiotherapy and chemotherapy is superior to radiotherapy alone in the treatment of locally advanced anal cancer: results of a phase III randomized trial of the European Organization for Research and Treatment of Cancer Radiotherapy and Gastrointestinal Cooperative Groups. J Clin Oncol 1997; 15: 2040-2049.

15. Gunderson LL, Winter KA, Ajani JA et al. Long-term update of US GI intergroup RTOG 98-11 phase III trial for anal carcinoma: survival, relapse, and colostomy failure with concurrent chemoradiation involving fluorouracil/mitomycin versus fluorouracil/cisplatin. J Clin Oncol 2012; 30: 4344-4351.

16. Frakulli R, Buwenge $M$, Cammelli $S$ et al. Brachytherapy boost after chemoradiation in anal cancer: a systematic review. J Contemp Brachytherapy 2018; 10: 246-253.

17. Gryc T, Ott O, Putz F et al. Interstitial brachytherapy as a boost to patients with anal carcinoma and poor response to chemoradiation: single-institution long-term results. Brachytherapy 2016; 15: 865-872.

18. Lestrade L, De Bari B, Pommier P et al. Role of brachytherapy in the treatment of cancers of the anal canal. Long-term follow-up and multivariate analysis of a large monocentric retrospective series. Strahlenther Onkol 2014; 190: 546-554.

19. Matthews JHL, Burmeister BH, Borg M et al. T1-2 anal carcinoma requires elective inguinal radiation treatment - the results of Trans Tasman Radiation Oncology Group study TROG 99.02. Radiother Oncol 2011; 98: 93-98.

20. Hannoun-Levi JM, Ortholan C, Resbeut M et al. High-dose split-course radiation therapy for anal cancer: outcome analysis regarding the boost strategy (CORS-03 study). Int J Radiat Oncol Biol Phys 2011; 80: 712-720.

21. Schernberg A, Bockel S, Annede P et al. Tumor shrinkage during chemoradiation in locally advanced cervical cancer patients: prognostic significance, and impact for image-guided adaptive brachytherapy. Int J Radiat Oncol Biol Phys 2018; 102: 362-372.

22. Schernberg A, Blanchard P, Chargari C, Deutsch E. Neutrophils, a candidate biomarker and target for radiation therapy? Acta Oncol 2017; 56: 1522-1530.

23. Schernberg A, Huguet F, Moureau-Zabotto L et al. External validation of leukocytosis and neutrophilia as a prognostic marker in anal carcinoma treated with definitive chemoradiation. Radiother Oncol 2017; 124: 110-117.

24. Schernberg A, Escande A, Rivin Del Campo E et al. Leukocytosis and neutrophilia predicts outcome in anal cancer. Radiother Oncol 2017; 122: 137-145. 


\section{Appendix}

\section{Quality of life survey}

1. For women only: do you have any gynecological problems?

1. Do you have pain in your lower abdomen?

No $\square$ Rarely $\square$ Sometimes $\square$ Often $\square$ All the time $\square$

- If so, how intense is it?

Low $\square$ Tolerable $\square$ Intense $\square$ Atrocious $\square$

2. Are you bothered with vaginal dryness?

No $\square$ Rarely $\square$ Sometimes $\square$ Often $\square$ All the time $\square$

- If so, do you use a lubricant?

No $\square$ Sometimes $\square$ Often $\square$

3. Are you concerned about a decrease in vaginal size?

No $\square$ Yes $\square$ Don't know $\square$

- If so, do you use vaginal dilators?

No $\square$ Yes $\square$ No longer currently $\square$

- Have you been told you have adhesions in your vagina?

No $\square$ Yes $\square$ Don't know $\square$

4. Do you have any vaginal bleeding outside of your period? No $\square$ Rarely $\square$ Sometimes $\square$ Often $\square$ All the time $\square$

5. Do you have any bowel or bladder discharges from the vagina?

No $\square$ Rarely $\square$ Sometimes $\square$ Often $\square$ All the time $\square$

\section{Do you have urinary problems?}

1. Do you feel pain when you urinate?

No $\square$ Rarely $\square$ Sometimes $\square$ Often $\square$ All the time $\square$

- If so, how intense is it?

Low $\square$ Tolerable $\square$ Intense $\square$ Atrocious $\square$

2. Do you have urine leaks?

No $\square$ Every month $\square$ Every week $\square$ Every day $\square$ All the time $\square$ During exertion or coughing apart from exertion or coughing $\square$

3. How often do you urinate?

Less than every 4 hours $\square$ Every 3-4 hours $\square$ Every 2-3 hours $\square$ Every 1-2 hours $\square$ Every hour $\square$

4. Do you have to get up at night to urinate?

No $\square$ Yes $\square$

- If so, how many times per night?

$0-1 \square \quad 2-3 \square$ 4-6 $\square 7$ or more $\square$

5. Have you noticed blood in your urine?

No $\square$ Rarely $\square$ Sometimes $\square$ Often $\square$ Constantly $\square$

6. Are you taking medication for your bladder?

Underwear protection (How many per day?

Self-survey (How many times a day?

Medication (Which ones:

\section{Do you have digestive problems?}

1. Do you have constipation?

No $\square$ Rarely $\square$ Sometimes $\square$ Often $\square$ Constantly $\square$

- If so, are you taking medication for your transit disorders?

No $\square$ Sometimes $\square$ Often $\square$

Which one?

2. Do you suffer from stool incontinence (leakage)?

No $\square$ Every month $\square$ Every week $\square$ Every day $\square$ All the time $\square$

3. Do you have "false needs"?

No $\square$ Rarely $\square$ Sometimes $\square$ Often $\square$ Constantly $\square$

4. Did you notice any blood in the stool?

No $\square$ Rarely $\square$ Sometimes $\square$ Often $\square$ Constantly $\square$

5. Do you have a stoma?

No $\square$ Yes $\square$

\section{Others}

1. Have you had any new procedures after the treatment of your disease?

No $\square$ Yes $\square$ (Which one?

2. Do you feel tired?

No $\square$ Rarely $\square$ Sometimes $\square$ Often $\square$ Constantly $\square$

- If so, why?

3. Does your health condition limit any of these activities? Significant physical exertion $\square$

Moderate physical exertion $\square$

Going up several floors $\square$

Going up a floor $\square$

Walk a hundred meters $\square$

Taking a shower or getting dressed $\square$

4. Do you have a professional activity (including studies)?

No $\square$ Yes $\square$

5. Do you feel sad or depressed?

No $\square$ Sometimes $\square$ Often $\square$

6. Overall, you think your health is:

Excellent $\square$ Very good $\square$ Good $\square$ Poor $\square \operatorname{Bad} \square$

7. Have you had any other serious illnesses affecting the small pelvis?

No $\square$ Yes $\square$ If yes, please specify: 